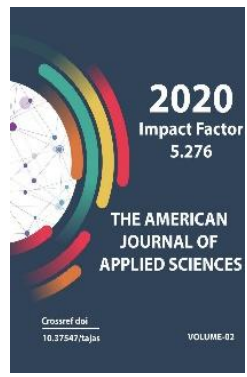

\title{
Influence Of The Ecological Disaster Of The Aral Sea On The Ecological And Social Feeling Of The Population
}

\author{
Eshmurodov Nabillo Ibodulla Ugli \\ 2nd Year Student Of The Magistracy Of The North Caucasus Federal University, Uzbekistan
}

Copyright: Original

content from this work

may be used under the

terms of the creative

commons attributes

4.0 licence.

\section{ABSTRACT}

This article examines the approaches of social ecology to the consideration of problems, as well as the application of one of them in the analysis of the social and environmental consequences of the ecological catastrophe of the Aral Sea.

\section{KEYWORDS}

Aral Sea, ecological disaster, sociology.

\section{INTRODUCTION}

Today we must talk about large-scale socioecological processes taking place in a society whose life takes place in an ecologically unfavorable and often crisis-prone natural environment. This is especially true of our country due to its size and uneven distribution of ecological and industrial zones.
One of the tasks of sociology is to study the ecological component of the social well-being of various social communities, which we call social and ecological well-being.

Social ecology as a field of sociology research can be divided into two main areas:

1. Study of social phenomena, social structures and processes in order to 
harmonize social relations and maintain social and environmental balance. In this context, sociology borrows the terminological and explanatory apparatus of environmental science and applies it to social phenomena and processes.

2. Research on the social aspects of environmental problems. In this context, ecological means natural. The emergence of social ecology as an independent sociological discipline became a stage in the formation of a "sociology of environmental problems", and in sociocultural terms, a stage in the development of an ecological problem as a social problem proper, where ecological knowledge acquires social value.

Let's move on to a specific example for research. In the past, the Aral Sea has played a decisive role in the development of the region's economy, its production sectors, creating jobs for the population and building a stable social infrastructure. On the fertile lands of the deltas of the Amu Darya and Syrdarya, as well as on highly productive pastures, tens of thousands of people worked in the fields of livestock, poultry and agricultural crops

\section{MATERIALS AND METHODS}

The problems of the Aral Sea emerged and became alarming in scale in the 1960s, when the region's main transboundary rivers, the SyrDarya and Amu Darya, were drastically regulated.

In connection with the drying up of the Aral Sea in the Aral Sea region, a complex complex of ecological, socio-economic and demographic problems has arisen, which has a global origin and a global scale of consequences and leads to the following negative consequences. Let's take a look at social issues.

Particularly noteworthy is the threat that, together with the high level of migration of the population associated with the deterioration of their living conditions due to the drying up of the Aral Sea, can lead to catastrophic consequences associated with the irrevocable disappearance of culture, traditions, spiritual and historical heritage. peoples of the region are linked

The most acute problem is the population's access to quality drinking water. More than half of the population of the Aral Sea zone, especially those living in rural settlements, are forced to use insufficiently purified water. According to official statistics, the provision of centralized water supply to apartments in the Republic of Karakalpakstan in 2006-2016 decreased from $71.3 \%$ to $66.6 \%$. In rural areas. there is essentially no centralized hot water supply (99.3\%), and decentralized water does not work in all households (27.5\%)

Water pollution and a large amount of dust and salt carried from the bottom of the dried Aral Sea play a decisive role in the growth of human morbidity, general and child mortality. Their consequence was high rates of a number of somatic diseases: anemia, kidney disease, gastrointestinal tract, an increase in the level of respiratory diseases, blood diseases, cholelithiasis, cardiovascular and oncological diseases.

The Aral Sea was one of the richest fishing grounds in the world. More than 80 percent of the inhabitants of the Aral Sea coast were engaged in catching, processing and transporting fish and fish products.

\section{RESULT AND DISCUSSION}

In the port cities, an integral infrastructure was created, shipyards serving ships, where up to 1.5 thousand people were provided with work on a permanent basis. Children's camps and holiday homes functioned on the coast, where thousands of children and adults came to rest every year. 
As a result of the loss of fishing and sea transport potential, industries such as fish processing and ship repair are out of order, tens of thousands of people were left without work. Three studies were conducted to measure self-esteem and psychosocial health, one in 2003 and the other in 2004. The experts asked mothers to classify the general health of children under 5 in school as "poor". perfectly". Mothers in Karakalpakstan and Khorezm were less likely to describe children's health with the epithets "excellent" and "very good" than mothers living in other regions of the country. The difference in the assessment of health as "satisfactory" was $10 \%$. All these and many other consequences, including economic ones, for the residents of adjacent territories can be called catastrophic. Social and environmental problems caused by the drying up of the Aral Sea have a great impact on the social and environmental well-being of people.

\section{REFERENCES}

1. Kasabutskaya M. S. - Social ecology and research of ecological consciousness in sociology: theoretical aspects [Electronic resource] // URL: https://cyberleninka.ru/article/n/sotsialnay a-ekologiya-i-issledovaniyaekologicheskogo-soznaniya -v-sotsiologiiteoreticheskie-aspekty

2. Aral Sea [Electronic resource] // URL: http://aral.mptf.uz/site/aralsea.html

3. The shallow Aral Sea - an ulcer of ill-being and ill health in Central Asia [Electronic resource] // URL: https://kazakhzerno.net/169538-obmelevshee-aralskoemore-jazva-neblagopoluchija-inezdorovja-v-centralnoj-azii / 